\title{
The Impact of the Economic Partnership Agreement on East African Community Trade with European Union: A Gravity Model Approach
}

\author{
Geoffrey Mwambe, Zawadi Ally, Don Prasad \\ Aldersgate College, Graduate School, Philippines
}

\begin{abstract}
This paper analyzes the impact of the Framework Economic Partnership Agreement (FEPA) on East African Community (EAC) trade with European Union (EU) for the period from 2000 to 2018. The analysis was carried out to estimate the impact of the interim EPA on EAC trade with EU using Gravity model approach. The variables employed in the study included trade flow of goods (exports and imports) between the two trade blocs, mass variables (real GDP growth, and per capita GDP) and dummy variables for capturing FEPA and time. The findings show that generally interim EPA did not benefit EAC economies and suggest potential for trade diversion. Burundi trade was adversely affected by FEPA while Kenya and Tanzania exports were positively impacted. The results may be influenced by weak productive capacities in EAC, global financial crisis which reduced global consumption demand, increased intra-EAC trade and trade with COMESA and SADC as well as low supply of goods for EU market.
\end{abstract}

Keywords: Gravity model approach, Economic Partnership Agreement, EAC, EU

DOI: $10.7176 / \mathrm{JESD} / 10-10-22$

Publication date:May $31^{\text {st }} 2019$

1 Introduction

Growth in world trade is in turn the result of both technological developments and concerted efforts to reduce trade barriers (IMF, 2001). Openness to trade (and foreign direct investment) has been an important element in the economic success of countries in East Asia, where the average import tariff has fallen from 30 percent to 10 percent over the past 20 years, with an impressive average growth rate of 8 percent per year (Rispens, 2009). Ward (2001) asserts that the miraculous of growth and economic development of the East Asian countries is the natural result of their liberal trade, outward-looking and market oriented policies. While expanding export markets are widely accepted as beneficial, increases in imports can be seen as threatening, replacing domestic production with goods and services from abroad (Amoah and Loloh, 2009). In small open economies like the EAC countries, external trade is an integral component of the nation's growth and development agenda. Consequently, the promotion of foreign trade has been central to all EAC government policies. Hence, at the end of 2007, the EAC countries comprising Burundi, Kenya, Rwanda, Tanzania and Uganda, entered into an inter-regional interim or the framework for an economic partnership agreement (FEPA) with the European Union counterparts.

The overall objectives of EPA are to contributing to economic growth and development; promoting regional integration, economic cooperation and good governance in EAC; promoting gradual integration of EAC into the world economy; fostering the structural transformation of EAC economies; improving EAC capacity in trade policy and trade-related issues; establishing and implementing an effective, predictable and transparent regional regulatory framework for trade and investment in EAC; and strengthening the existing relations between EAC and EU on the basis of solidarity and mutual interest. Under the agreement, goods traded among the parties will be accorded favourable treatment relative to those originating outside the two regions regardless of their membership status with the WTO. Economic theories and empirical studies have pointed out that trade liberalization across borders of participating members in a regional trade arrangement may lead to an increase in both intra-regional and external trade. This may be a result of increased competition, capital flows and larger markets for local producers. Dollar (1992) asserts that a well-designed trade agreement increases competition among domestic firms and promote productive efficiency gains. This improves quality and quantity of inputs and goods available to the economy. However, some other studies indicate that trade agreements may have trade diverting effects away to non-member countries and it is difficult to assess a priori whether such trade creation will outweigh trade diversion effects (Clausing, 2001). Despite the ambiguity regarding the benefits, it is expected that the EAC-EU EPA agreement will create more trade than diverting away from the two regions. It can be hypothesized that, the EAC is likely to increase its exports following granting a DFQF access for all its goods and services (including those not covered under the Cotonou Agreement) to the EU market. It is important to investigate the implications of the EAC countries by negotiating, signing, implementing and evaluating full EPA on the trade performance in the short, medium and long run. The gravity model approach has assumed great prominence in explaining the trade 
pattern in emerging economies countries, especially in Latin America and Asia, as the model provides a practical framework for evaluating the changing pattern in international trade and growing intra-developing economies countries trade. Therefore, this study will attempt to investigate the applicability of the gravity model approach in analyzing the pattern of EPA between EAC and EU.

The rest of the paper is organized as follows: section two presents' reviews of the theoretical frameworks and empirical studies that have been used to explain the pattern of EPA among regions while section three discusses the methodology, data and variables used in this study. Section four presents and discusses the empirical findings and section five draws conclusion and policy implications.

\subsection{Literature Review \\ 2.1 Theoretical Literature Review}

Over several years, the gravity model approach has been the workhorse of empirical studies since its first application to analyze the determinants of bilateral trade flows by its pioneers, Tinbergen (1962) and Pöyhönen (1963). The gravity model studies have been extensively used to highlighting the importance of analyzing the determinants of bilateral trade flows. The analysis of this study is done using the Gravity model developed by Jan Tinbergen (1962) which is based on Viner's model (1950) to examine the trade (creation and diversion), economic and welfare effects of the regional integration arrangements. The effects are best explained by the theory of trade creation and trade diversion based on the conventional interpretation of Viner's model (1950). According to the theory, when barriers to trade are reduced among trading countries, markets tend to enlarge thus giving more efficient producers entry into countries where prices are naturally high. Subsequently, the consumer choices and competition among producers increase and thereby attain positive benefits of the integration arrangement. However, the benefits may vary from either one integration arrangement to another or one participating country to another depending on the level of preparedness, supply/ productive capacities, trade facilitation instruments (including infrastructure, non-tariff barriers, investments, etc) and the preferential treatment accorded to the agricultural products. According to Viner (1950), trade diversion on the one hand occurs when a customs union (or an FTA) diverts trade away from a more efficient supplier outside the trade bloc towards a less efficient supplier within the union or an FTA. The likely effect may either be a reduction or an improvement in welfare despite the trade diversion. On the other hand, trade creation occurs when a customs union (or an FTA) creates trade that would not have existed otherwise without the formation of the customs union (or an FTA). Unlike the case of trade diversion, trade creation results into increase in supply from a more efficient producer of a given product. Kwaku (1995) suggests that the main driver for increasing number of RIAs in the African subcontinent is the need to achieve regional cooperation by creating a unified economic bloc. In addition, it is envisaged that RIAs will be the building blocks for stronger integration between countries for eventual creation of an African Economic Community (UNECA, 2012). WB (2005) suggests that regionalism in Africa has potential to pool the underutilized resources and fragmented African markets, promote industrialization and act as a useful alternative to unilateral trade liberalization.

\subsection{Empirical Studies on gravity Model Approach}

Tinbergen (1962) was the first to publish an econometric study employing the gravity equation for international trade flows. In his study involving data on 18 countries in 1958, the study found that both incomes and distance had their expect signs and were statistically significant. Bergstrand (1990) employed an augmented version the gravity equation to analyze the determinants of bilateral exports among 15 OECD countries in 1976. In addition to the conventional gravity variables, the study included exchange rate, price indices for exports and imports, the study found that the economic size of countries, import price index, adjacency and EFTA membership had significantly positive effects on exports between two trading countries, whilst the geographic distance between them was found to reduce the volume of exports of these countries. The other variables were found to be statistically insignificant.

Gani (2008) examined the factors influencing trade between Fiji and its Asian partners, using a panel data for the period 1985 to 2002 over a cross-section of seven Asian countries for the import model and five for the export model. Within the framework of the gravity model, Gani (2008) postulated that Fiji's imports from and exports to its Asian partners at time $t$ are determined by their GDPs the geographic distance between Fiji and the major port of entry of an Asian country, and other possible influences such as the exchange rate and infrastructure. The results obtained from the panel data estimation procedure indicate that imports by Fiji from Asia are significantly influenced by the population and the infrastructure of the Asian countries and the distance between Fiji and the exporting country. Rahman (2009) applied generalized gravity models to explore Australia's global trade potential with its 57 trading partners for the period of 1972-2006. In this study, the standard gravity model was 'augmented' by including GDP per capita of Australia and its partners, the per capita GDP differential between Australia and 
its partners, openness of its partners and dummies for common language and RTA membership. By employing panel data estimation techniques to estimate the specified model, the estimated coefficients were then used to predict Australia's trade potential. The results revealed that Australia's bilateral trade is affected positively by income, openness of trading partners, common language and free trade agreement, and negatively by the per capita income differential (thus providing evidence for the Linder hypothesis) and distance between Australia and trading partners. The results indicated that Australia has notable trade potential with Mexico, Argentina, Uruguay, Austria, Peru, India, the Philippines, Brazil, Chile, the U.S., New Zealand, Greece, Japan, Turkey, Nepal, Kenya, Spain, Hungary, Brunei, Hong Kong, South Africa, Pakistan and Canada. Roy and Rayhan (2011) analyzed the determinants of trade flows in Bangladesh through gravity model panel data approach for the period from 1991 to 2007 the results showed that both basic and extended gravity models were established, which implied that Bangladesh's trade flows are significantly determined by the size of Bangladesh's economy and that of its partners, openness of the partner's economy and exchange rate.. Abedini and Peridy (2008) undertook analysis of the GAFTA agreement effects using panel data involving 15 GAFTA countries, 8 GAFTA candidate countries, the study found a 20 percent increase in trade flows between regions belonging to the GAFTA agreement. Grant and Lambert (2008) investigated the trade flow effects of Regional Trade Agreements (RTAs) covering the period 1982-2002 for agricultural and non-agricultural commodities.. The study which employed OLS fixed effects indicates that the type and characteristics of trade agreements for agricultural products play a significant role in actually improving trade, while positive effects to trade may not occur immediately. Kalijaran (2007) employed panel data covering for 1992-1996 and 1999-2002 to estimate using GLS the effects of GDP, GDP per capita, population, distance and APEC membership on exports. The results show that Australia was expected to have more gains of its potential exports because of the IOR-ARC agreement. In their study that examined FTA effects, Baier and Bergstrad (2007) using panel data attempted to clarify the effects of FTAs in trade, by exploiting the prevailing theoretical background of the gravity model and modern econometric studies. They applied bilateral trade flows for dependent variable and GDP, distance, common border, common language and FTA membership for explanatory variables. The study employed ordinary least square (OLS) technique with fixed effects, two-way fixed effects, random effects and differentiated estimates. Their treatment of the FTAs as endogenous variables, subject to interaction effects, led to the conclusion that FTAs do affect trade considerably. Using panel data for 50 countries, Lee and Park (2007) undertook an investigation of optimized regional trade agreements for East Asia covering the period 1994-1999. They used the OLS estimation technique with fixed and random effects to examine the effects that GDP. GDP per capita, distance, country surface area, common border, common language, common colonizer, colony (past or present), and participation in currency union, tariff, trade facilitation and FTA membership have on bilateral trade flows. The authors proposed new FTAs for East Asia and noted that trade facilitation would enhance trade creation between FTA members and reduces trade diversion among them. Moreover, they indicated that their proposed. Péridy (2005) used panel data for the period 1975-2001 to investigate EU Mediterranean FTA (EMFTA) effects to trade for Mediterranean countries with 42 trading partners. The study used exports as endogenous variable and GDP, per capita GDP, country similarity in size, distance, border type, regional arrangement between EU and Mediterranean countries and language as explanatory variables. The study applied the OLS estimation technique with fixed and random effects. He reported that the FTA resulted in an increase of Mediterranean countries' exports to the EU by 20-27 percent, indicating trade creation and accounted for the large EU share of Mediterranean exports. Tang (2005) examined the effects of the NAFTA, ANZCER and ASEAN FTAs using panel data for 21 member and nonmember countries for the period 1989-2000. Tang applied exports as dependent variable and GDP, GDP per capita, distance, volatility of exchange rate, income similarity, developed/ developing country, NAFTA membership for both or one partner, ANZCER membership for both or one partner, and ASEAN membership for both or one partner as independent variables. The study which employed OLS and 2SLS estimation techniques found that trade within member countries has increased. While ANZCER FTA was found to result in trade diversion from non-members, ASEAN FTA has led to a trade increase with nonmembers (something that has not been observed for NAFTA.

Many studies have provided empirical evidences on the effects of the FTAs in the globe. Some studies found FTAs to have trade creation or trade diversion effects or both depending on the specific characteristics of the FTA in question. In general, studies indicate that a well-designed FTA can result into trade creation whereby imports from non-FTA member economies are replaced by efficient domestic suppliers in the region. However, to our knowledge no study has been conducted to analyze the effect of the interim EPA between EAC and EU trade using a gravity model approach. Therefore, this study will bridge the knowledge gap by analysing the impact of framework for the EPA on EAC trade with EU by employing the gravity model approach.

\section{Methodology}

This study predicts the trade creation and trade diversion potential of the full EPA. The analysis will be based on the gravity model developed by Tinbergen (1962) built on the foundations from the work of Viner (1950). To start 
with, the study will assess the economic and trade performances of the two regions and later evaluates both the then Cotonou and FEPA. The evaluation will help to obtain key elements and the substantial difference between the two.

\subsection{Model Specification}

For the purpose of empirical estimation of the model and need for testing for inferential statistics, the study introduces logarithm to transform the expression into logarithmic form.

\subsubsection{Gravity equation for FEPA effect on EAC exports}

For estimation, the study included an error term, $\varepsilon_{\mathrm{ij}}$, to capture unexplained part of the model. The gravity equation for exports becomes:

$$
\ln X_{i j}=\ln K+\beta_{1} \ln Y_{i}+\beta_{2} \ln y_{j}+\beta_{3} \operatorname{rgdpg} g_{i}+\varepsilon_{i j}
$$

Where $\beta$ 's are coefficients to be estimated while $y_{j}$ is per capita GDP of the importing economy $j$ the hypothesized relationship above indicate that $\beta_{1}, \beta_{2}, \beta_{3}>0$. Since the estimation of this gravity equation used panel dataset to capture the effects at different periods of EAC and EU trading arrangement, then time aspect is introduced into the equation to looks as follows:

$\ln X_{i j}^{t}=\ln K+\beta_{1} \ln Y_{i}^{t}+\beta_{2} \ln y_{j}^{t}+\beta_{3} r g d p g_{i}+Y r s+\varepsilon_{i j}^{t}$

Where, the t-superscript represents the year of the observation and Yrs is a set of indicator variables for all the years in the sample except the first.

Now, to capture the FTA's trade creation and trade diversion effects, we introduce the relevant variables. For observations where both the importing and exporting economies are the TFA members in year $t$ the variable is $E P A_{i j}$, and for observations where the importing economy is the FTA member in year $t$ but the exporting member is not. $E P A_{i j}$ measures trade creation and it expect that $E P A_{i j}>0$ while 1-FEP $A_{i j}$ measures trade diversion away from FTA. Thus, the gravity equation becomes:

$\ln X_{i j}^{t}=\ln K+\beta_{1} \ln Y_{i}^{t}+\beta_{2} \ln y_{j}^{t}+\beta_{3} r g d p g_{i}+\beta_{4} E P A_{i j}+\beta_{5} Y r s+\varepsilon_{i j}^{t}$

It is expected that:

- $\quad$ higher the GDP in the economy $i\left(\mathrm{Y}_{\mathrm{i}}\right)$, the higher the exports by economy $j$;

- $\quad$ higher the per capita GDP of importing economy $j\left(y_{j}\right)$, the higher the exports from $i$;

- $\quad$ higher the real GDP growth of country $i$, the higher the exports to economy $j$;

- $\quad$ positive coefficient of $E P A_{i j}$ to imply trade creation and negative coefficient to imply trade diversion following implementation of framework EPA;

- Coefficient of Yrs represents time trending effects of EAC-EU trade prior to and post FEPA.

\subsubsection{Gravity equation for FEPA effect on EAC imports:}

For imports, the study considered modification of gravity equation (3.3) as follows:

$L n M t i j=\ln K+\beta_{1} \ln Y_{j}^{t}+\beta_{2} \ln y_{i}^{t}+\beta_{3} E P A_{i j}+\beta_{4} Y r s+\varepsilon_{i j}^{t}$

It is expected that:

- $\quad$ higher the GDP in the economy $j\left(\mathrm{Y}_{\mathrm{j}}\right)$, the higher the imports by economy $i$;

- $\quad$ higher the per capita GDP of importing economy $i\left(y_{i}\right)$, the higher the imports from $j$;

- $\quad$ positive coefficient of $E P A_{i j}$ to imply trade creation and negative coefficient to imply trade diversion following implementation of FEPA; 
- Coefficient of $Y r s$ represents time trending effects of EAC-EU trade prior to and post FEPA.

\subsection{Dataset for Analysis}

The study analyzed the gravity model using goods exports and imports functions. The study used panel datasets for the period 1990 to 2018 to analyze the trade effects of the EAC-EU EPA on the five East African Community member states namely, Burundi, Kenya, Rwanda, Tanzania and Uganda. The period is long enough to capture the effects of Cotonou Agreement that commenced in 2000 as well as the implementation of framework for EPA since 2008. Like many previous studies, this study employs panel datasets for the analysis of the trade effects of the EAC-EU EPA.

\subsection{Variables for Analysis}

This study employed bilateral exports and imports as dependent variables to represent trade flows $\left(\mathrm{TF}_{\mathrm{ij}}\right)$ from one economic region $(i)$ to another $(j)$. The explanatory variables used in the gravity model specification for this study were in three categories: mass variables for economic region $i,\left(\mathrm{M}_{\mathrm{i}}\right)$ that include GDP, per capita GDP and real GDP growth; destination economic region $j$; and impedance variables between economic regions $i$ and $j$, ( $\left(\mathrm{I}_{\mathrm{ij}}\right)$ such as existence of other FTA arrangements, CPI, terms of trade indexes, trade openness and distance to the rest of the major trading partners. This study applied the mass variables which are included in most gravity model specifications to represent demand and supply.

\subsection{Data sources}

The data for analysis were obtained from the World Bank database, the International Monetary Fund's International Financial Statistics (IMF IFS), Direction of Trade Statistics (DOTS), the European Union database, the WTO trade statistics, the East African Community database, UNCTAD, COMTRADE, and various other relevant sources.

\subsection{Empirical Results and Discussion}

This section discusses empirical results, the gravity model was employed to estimate EAC export and import functions using Stata. The functions were estimated to examine the effects of FEPA on EAC trade with EU. The GDP growth of EAC, GDP growth of EU and the time period were incorporated into the functions as control variables. The analysis was carried out for five EAC countries, each with 29 observations to make a total of 145 observations. Further, xtset-test per country per year carried out indicated that panel variable is strongly balanced covering the years 1990 to 2018 with a delta of 1 unit.

\subsection{Regression results for Burundi Exports to EU}

The estimation of Burundi's export equation was done using OLS and the goodness of fit of the estimated model was strong with adjusted R-squared of 0.7827 and Prob $>F=0.0037$ with 5 degrees of freedom. Regression analysis for Burundi's export function found that the regression coefficient had a negative sign, indicating a decline in exports to EU following implementation of an interim EPA. Overtime, FEPA implementation yielded negative growth of the country's exports to EU which suggests presence of trade diversion effect as the coefficient of variable year was found to be negative. This means that Burundi traded more with non-EU countries during implementation of an interim EPA.

Table 4.1: Estimation results for Burundi exports to EU, 1990-2018

\begin{tabular}{|c|c|c|c|c|c|c|}
\hline $\log X_{i j}$ & Coef. & Std. Err. & $\mathrm{t}$ & $\mathrm{P}>|\mathrm{t}|$ & \multicolumn{2}{|c|}{ [95\% Conf. Interval] } \\
\hline$f e p a_{i j}$ & -0.7573851 & 0.3741991 & -1.76 & 0.113 & -1.503882 & 0.1891121 \\
\hline year & -0.0476637 & 0.1240972 & -0.30 & 0.768 & -0.318391 & 0.2430636 \\
\hline $\log _{-} y_{i}$ & 2.0778450 & 0.4773075 & 5.45 & 0.002 & 0.9981003 & 3.1575890 \\
\hline${\log \_r g d p g_{i}}$ & -0.3574194 & 0.1483277 & -1.53 & 0.160 & -0.5629599 & 0.1081213 \\
\hline $\log y_{j}$ & -0.8358377 & 2.8623160 & -0.22 & 0.832 & -7.1008360 & 5.8491810 \\
\hline cons & 81.190920 & 239.65800 & 0.32 & 0.753 & -425.02900 & 567.41090 \\
\hline
\end{tabular}

Source: Author Computed by STATA

GDP of Burundi $\left(\log y_{i}\right)$ had t-statistic of 5.45 and with $\mathrm{P}>|\mathrm{t}|=0.012$ and it is statistically significant at 5 percent level of significance. This implies that GDP was positively related to the increase in the country's exports to the EU market. Both real GDP growth for Burundi $\left(\log _{-} r g d p g_{i}\right)$ and GDP of EU $\left(\log _{-} y_{j}\right)$ were found to be negatively 
related to exports, have low $t$-statistic ratios and statistically not significant. The implication is that FEPA has resulted into decline in Burundi's exports to EU and hence unfavourable.

\subsection{Regression results for Burundi Imports to EU}

Estimation results reveal that FEPA had a negative impact on Burundi's imports from EU. The regression coefficient of FEPA $\left(f e p a_{i j}\right)$ is -0.0459375 , indicating decrease in imports from EU following FEPA. Real GDP of EU and Burundi were both positively related to the increase in Burundi imports from EU with $t$-statistics of 4.61 $(\mathrm{P}>|\mathrm{t}|=0.003)$ and $4.73(\mathrm{P}>|\mathrm{t}|=0.000)$ at all levels of significance. Effect of the year was found to be negative, implying a decreasing trend of imports from EU to the country and hence trade diversion effect. The goodness of fit of the estimated model as measured by adjusted R-squared was 0.8868 with Prob $>F=0.000$. It implies relative adequacy of the independent variables in explaining a unit change in imports from EU.

Table 4.2: Estimation results for Burundi imports to EU, 1990-2018

\begin{tabular}{|c|c|c|c|c|c|c|}
\hline log_Mij & Coef. & Std. Err. & $\mathrm{t}$ & $\mathrm{P}>|\mathrm{t}|$ & \multicolumn{2}{|c|}{ [95\% Conf. Interval] } \\
\hline$f e p a_{i j}$ & -0.0459375 & 0.1508997 & -0.22 & 0.830 & -0.349956 & 0.284101 \\
\hline $\log _{\triangle} y_{j}$ & 1.1439850 & 0.3260738 & 4.61 & 0.013 & 0.4589291 & 1.829040 \\
\hline $\log _{-} y_{i}$ & 2.3680760 & 0.5001683 & 4.73 & 0.000 & 1.3172620 & 3.418891 \\
\hline year & -0.0550727 & 0.0160862 & -3.42 & 0.003 & -0.0888684 & -0.021277 \\
\hline cons & 88.622600 & 31.254370 & 2.84 & 0.011 & 22.959600 & 154.2856 \\
\hline
\end{tabular}

Source: Author Computed by STATA

\subsection{Regression Results for Kenya Exports to EU}

Kenya's export model had high goodness of fit with adjusted R-squared of 0.9287 and Prob $>\mathrm{F}=0.000$ at 5 degrees of freedom. Estimation results revealed that regression coefficient for FEPA $\left(\right.$ fepa $\left._{i j}\right)$ is positive, indicating FEPA had positive contribution to increase in the country's exports to the EU market. Kenya's real GDP $\left(\log y_{i}\right)$ was found to have positive relationship with exports to EU and its regression coefficient has t-statistic of 3.54 with $\mathrm{P}>|\mathrm{t}|=0.022$. It is statistically significant at 5 percent level of significance. Real GDP growth for Kenya $\left(\log r g d p g_{i}\right)$ and GDP for EU $\left(\log y_{j}\right)$ are not statistically significant. Although their regression coefficients are positive, they have low $t$-statistic ratios.

Table 4.3: Estimation results for Kenya Exports from EU, 1990-2018

\begin{tabular}{|c|c|c|c|c|c|c|}
\hline $\log \mathrm{Xij}_{\mathrm{ij}}$ & Coef. & Std. Err. & $\mathrm{t}$ & $\mathrm{P}>|\mathrm{t}|$ & \multicolumn{2}{|c|}{ [95\% Conf. Interval] } \\
\hline fepa $_{i j}$ & 0.1673728 & 0.0881519 & 1.90 & 0.076 & -0.0195010 & 0.3542465 \\
\hline year & -0.0473788 & 0.0340556 & -1.39 & 0.183 & -0.1195733 & 0.0248158 \\
\hline $\log _{-} y_{i}$ & 0.3544569 & 0.1529107 & 3.54 & 0.022 & 0.0303008 & 0.6786130 \\
\hline $\log _{-} r g d p g_{i}$ & 0.0404606 & 0.0267313 & 1.51 & 0.150 & -0.0162072 & 0.0971283 \\
\hline $\log _{-} y_{j}$ & 1.213269 & 0.8164242 & 1.49 & 0.157 & -0.5174728 & 2.9440110 \\
\hline cons & 88.06372 & 60.461610 & 1.42 & 0.174 & -42.099270 & 214.24650 \\
\hline
\end{tabular}

Source: Author Computed by STATA

The coefficient of variable year was found to be negative implying that as time go Kenya exported its goods and services away from EU markets during the implementation of the interim EPA and hence trade diversion effect.

\subsection{Regression Results for Kenya Imports to EU}

Model specification for estimation of Kenya's import function was correct and adequate with adjusted R-squared of 0.9867 and Prob $>\mathrm{F}=0.000$. Regression coefficient for interim EPA $\left(f e p a_{i j}\right)$ was found to be positive at 0.1072963 implying a positive impact of FEPA in Kenya's imports from EU. The model controlled for GDP of both EU $\left(\log \__{-} y i\right)$ and EAC $\left(\log \_y i_{-}\right)$which were also found to have a positive impact on imports. 
Table 4.4: Estimation results for Kenya imports to EU, 1990-2018

\begin{tabular}{|c|c|c|c|c|c|c|}
\hline $\log \_\mathrm{Mij}$ & Coef. & Std. Err. & $\mathrm{t}$ & $\mathrm{P}>|\mathrm{t}|$ & \multicolumn{2}{|c|}{ [95\% Conf. Interval] } \\
\hline$f e p a_{i j}$ & 0.1072963 & 0.0751461 & 1.44 & 0.167 & -0.0495899 & 0.2661622 \\
\hline $\log _{-} y_{j}$ & 0.3866189 & 0.2115492 & 1.78 & 0.097 & -0.0578296 & 0.8310673 \\
\hline $\log _{-} y_{i}$ & 3.0677770 & 0.5892601 & 7.31 & 0.000 & 1.8297870 & 4.3057660 \\
\hline year & -0.0615075 & 0.0112598 & -5.46 & 0.000 & -0.0851630 & -0.0378515 \\
\hline cons & 104.00910 & 19.421400 & 5.36 & 0.000 & 63.2062600 & 144.81190 \\
\hline
\end{tabular}

Source: Author Computed by STATA

However, GDP of EU did not seem to be statistically significant at 5 percent level of significance as result shows $t$-statistic to be 1.78 with $\mathrm{P}>|\mathrm{t}|=0.097$. Real GDP of Kenya was found to be positive and significant at $t$-statistic of 7.31 with $\mathrm{P}>|\mathrm{t}|=0.000$ at all levels of significance. Like all other countries, Kenya's imports were found to be negatively impacted by the implementation of FEPA overtime and hence trade diversion effect.

\subsection{Regression results for Rwanda Exports to EU}

The goodness of fit of the estimated model for Rwanda's exports to EU was found to be good and adequate with high adjusted R-squared of 0.8851 and Prob $>\mathrm{F}=0.000$ at 5 degrees of freedom. Estimation results of the model reveal that Rwanda's exports to EU was negatively affected by FEPA implementation as regression coefficient for FEPA $\left(f_{\text {ep }} a_{i j}\right)$ was -0.4448448 . The negative sign implies negative effect of FEPA implementation on a unit change in the country's exports to EU. Rwanda's real GDP $\left(\log y_{i}\right)$ had positive regression coefficient and statistically significant at all levels of significance. Rwanda's real GDP growth $\left(\log _{-} r g d p g_{i}\right)$ and GDP for EU $\left(\log _{-} y_{j}\right)$ have low $t$-statistic ratios and are not statistically significant although their regression coefficients are positive. Overtime, FEPA implementation led to decline in exports to EU which implies trade diversion effect.

Table 4.5: Estimation results for Rwanda exports to EU, 1990-2018

\begin{tabular}{|c|c|c|c|c|c|c|}
\hline $\log X_{i j}$ & Coef. & Std. Err. & $\mathrm{t}$ & $\mathrm{P}>|\mathrm{t}|$ & \multicolumn{2}{|c|}{ [95\% Conf. Interval] } \\
\hline$f e p a_{i j}$ & -0.4448448 & 0.2503243 & -1.38 & 0.192 & -0.8855366 & 0.1960490 \\
\hline year & -0.2337834 & 0.0812649 & -2.88 & 0.013 & -0.4093455 & -0.0582213 \\
\hline $\log _{-} y_{i}$ & 1.9094330 & 0.2628838 & 7.26 & 0.000 & 1.3415070 & 2.4773590 \\
\hline${\log \_r g d p g_{i}}_{1}$ & 0.0689493 & 0.0874521 & 0.79 & 0.445 & -0.1199795 & 0.2578781 \\
\hline $\log _{-} y_{j}$ & 1.8650940 & 1.7933130 & 1.04 & 0.317 & -2.0091230 & 5.7393120 \\
\hline cons & 438.20930 & 145.04050 & 3.02 & 0.010 & 124.86830 & 751.55040 \\
\hline
\end{tabular}

Source: Author Computed by STATA

\subsection{Regression results for Rwanda Imports from EU}

Estimated Rwanda's import model was correct and strong in explaining the influence of the independent variables on a unit change of imports from EU. The model had a high goodness of fit with adjusted R-squared of 0.9546 and Prob $>F=0.000$. The results of the analysis reveal that an interim EPA had a positive impact on the change in imports for the country evidenced by regression coefficient of 0.5843581 . Except for the year variable, GDP for EU and Rwanda were both positive and statistically significant at all significance levels. GDP for EU and Rwanda had $t$-statistics of 5.68 and 5.62 with $\mathrm{P}>|\mathrm{t}|=0.000$ for both. As time went, Rwanda imported more from non-EU countries despite the interim EPA, indicating trade diversion effects. 
Table 4.6: Regression results for Rwanda Imports from EU, 1990-2018

\begin{tabular}{|c|c|c|c|c|c|c|}
\hline $\log _{-} M_{i j}$ & Coef. & Std. Err. & $\mathrm{t}$ & $\mathrm{P}>|\mathrm{t}|$ & \multicolumn{2}{|c|}{ [95\% Conf. Interval] } \\
\hline$f e p a_{i j}$ & 0.5843581 & 0.1129464 & 4.19 & 0.001 & 0.2360666 & 0.7106496 \\
\hline $\log _{-} y_{j}$ & 1.3172030 & 0.2903491 & 5.68 & 0.000 & 0.7072017 & 1.9272030 \\
\hline $\log _{-} y_{i}$ & 0.9817471 & 0.2219928 & 5.62 & 0.000 & 0.5153575 & 1.4481370 \\
\hline year & -0.079408 & 0.0128315 & -6.19 & 0.000 & -0.1063661 & -0.0524503 \\
\hline cons & 144.70050 & 23.522730 & 6.15 & 0.000 & 95.2811000 & 194.12000 \\
\hline
\end{tabular}

Source: Author Computed by STATA

\subsection{Regression Results for Uganda Exports to EU}

Uganda's export model was estimated using OLS. The model had high goodness of fit (adjusted R-squared = 0.7554 and Prob $>F=0.000$ ) at 5 degrees of freedom. The estimation results show that the regression coefficient of FEPA $\left(\right.$ fepa $\left._{i j}\right)$ was negative. This implies that implementation of FEPA had a negative impact on Uganda's exports to EU. For the other variables, only real GDP of Uganda $\left(\log _{-} y_{i}\right)$ had positive coefficient with high $t$ statistic ratio of 4.76 and $\mathrm{P}>|\mathrm{t}|=0.003$ which is significance. Trade diversion is found to take effect following a negative coefficient of variable year.

Table 4.7: Estimation results for Uganda exports to EU, 1990-2018

\begin{tabular}{|c|c|c|c|c|c|c|}
\hline $\log X_{i j}$ & Coef. & Std. Err. & $\mathrm{t}$ & $\mathrm{P}>|\mathrm{t}|$ & \multicolumn{2}{|c|}{ [95\% Conf. Interval] } \\
\hline$f e p a_{i j}$ & -0.4616654 & 0.2663118 & -1.32 & 0.204 & -0.913534 & 0.2102037 \\
\hline year & 0.0714669 & 0.1192552 & 0.60 & 0.557 & -0.1801396 & 0.3230735 \\
\hline $\log _{-} y_{i}$ & 1.6177820 & 0.4300976 & 4.76 & 0.002 & 0.7103552 & 2.5252090 \\
\hline${\log \_r g d p g_{i}}$ & 0.2268582 & 0.2022230 & 1.12 & 0.278 & -0.1997950 & 0.6535115 \\
\hline $\log _{-} y_{j}$ & -3.0767280 & 2.6548290 & -1.16 & 0.263 & -8.6779280 & 2.5244720 \\
\hline cons & -121.10350 & 212.25210 & -0.57 & 0.576 & -568.91620 & 326.70910 \\
\hline
\end{tabular}

Source: Author Computed by STATA

\subsection{Regression Results for Uganda Imports from EU}

Analysis of the import function for Uganda showed that the model for estimation was correctly specified as the adjusted R-squared was 0.96880 with $P r o b>F=0.000$. Regression coefficient of $f e p a_{i j}$ was positive, implying that EPA impacted positively on Uganda's imports sourced from EU countries. Other independent variables namely GDP of EU $(\log Y j)$ and EAC $(\log y i)$ were also found to be positive and significant at 5 percent level of significance. The $\mathrm{t}$-statistics for the two variables are 5.48 and 3.78 with $\mathrm{P}>|\mathrm{t}|=0.000$ and $\mathrm{P}>|\mathrm{t}|=0.013$, respectively. Overtime, effect of FEPA was negative since its implementation suggesting trade diversion effect.

Table 4.7: Estimation results for Uganda imports from EU, 1990-2018

\begin{tabular}{|c|c|c|c|c|c|c|}
\hline log_Mij & Coef. & Std. Err. & $\mathrm{t}$ & $\mathrm{P}>|\mathrm{t}|$ & \multicolumn{2}{|c|}{ [95\% Conf. Interval] } \\
\hline$f_{e p a_{i j}}$ & 0.3206513 & 0.0876871 & 2.40 & 0.027 & 0.0264275 & 0.3948752 \\
\hline $\log y_{j}$ & 1.298779 & 0.2416161 & 5.48 & 0.000 & 0.7911627 & 1.8063960 \\
\hline $\log y_{i}$ & 2.289193 & 0.833081 & 3.78 & 0.013 & 0.5389545 & 4.0394310 \\
\hline year & -0.1233782 & 0.0407476 & -3.03 & 0.007 & -0.2089857 & 0.0377707 \\
\hline cons & 225.2238 & 76.753450 & 2.93 & 0.009 & 63.970800 & 386.47680 \\
\hline
\end{tabular}

Source: Author Computed by STATA

\subsection{Regression Results for Tanzania Exports to EU}

Regression analysis for Tanzania's export function was carried out and found that the model was correctly specified as the goodness of fit as measured by adjusted R-squared was 0.8875 and Prob $>F=0.000$. Estimation obtained similar results to that of Kenya whereby regression coefficient for FEPA $\left(f_{e p a} a_{i j}\right)$ is positive, indicating that implementation of EPA led to increase in the country's exports to the EU market although it is statistically not significant. However, other variables were found to have low t-statistic ratios and not statistically significant 
at 5 percent significance level. Further, real GDP of Tanzania $\left(\log y_{i}\right)$ had negative regression coefficient. The coefficient of variable year is negative indicating that overtime Tanzania's exports to the EU decreased as they found non-EU markets and hence suggest trade diversion. Nevertheless, the variable year is statistically not significant as it was found to have low $t$-statistic ratio.

Table 4.9: Estimation results for Tanzania Exports to EU, 1990-2018

\begin{tabular}{|c|c|c|c|c|c|c|}
\hline $\log \_X_{i j}$ & Coef. & Std. Err. & $\mathrm{t}$ & $\mathrm{P}>|\mathrm{t}|$ & \multicolumn{2}{|c|}{ [95\% Conf. Interval] } \\
\hline$f_{e p a_{i j}}$ & 0.1167100 & 0.1114518 & 1.05 & 0.310 & -0.1184326 & 0.3518527 \\
\hline year & 0.0101977 & 0.0512902 & 0.20 & 0.845 & -0.0980152 & 0.1184106 \\
\hline $\log _{-} y_{i}$ & -0.1554545 & 0.3128685 & -0.50 & 0.626 & -0.8155494 & 0.5046404 \\
\hline${\log \_r g d p g_{i}}_{1}$ & 0.0521435 & 0.0643568 & 0.81 & 0.429 & -0.0836375 & 0.1879245 \\
\hline $\log _{-} y_{j}$ & 1.0766950 & 1.1024090 & 0.98 & 0.342 & -1.2491840 & 3.4025740 \\
\hline cons & -24.041800 & 92.034800 & -0.26 & 0.797 & -218.21830 & 170.134700 \\
\hline
\end{tabular}

Source: Author Computed by STATA

\subsection{Regression Results for Tanzania Imports from EU}

Estimation results indicate that Tanzania's import function was correctly specified with adjusted R-squared = 0.9634 and Prob $>F=0.000$. The analysis found that FEPA was positively related to a unit change in the country's imports from EU with a regression coefficient of 0.2835486. GDP of EU and that of EAC were also found to be positive and significant in explaining a unit change of imports from EU. Their regression coefficients were 1.052944 and 2.841473 with $t$-statistics of $4.61(\mathrm{P}>|\mathrm{t}|=0.000)$ and $5.68(\mathrm{P}>|\mathrm{t}|=0.000)$ at 5 percent and all significance levels, respectively.

Table 4.10: Estimation results for Tanzania Imports from EU, 1990-2018

\begin{tabular}{|c|c|c|c|c|c|c|}
\hline log_Mij & Coef. & Std. Err. & $\mathrm{t}$ & $\mathrm{P}>|\mathrm{t}|$ & \multicolumn{2}{|c|}{ [95\% Conf. Interval] } \\
\hline$f_{e p a} a_{i j}$ & 0.2835486 & 0.1062429 & 1.73 & 0.101 & -0.0396592 & 0.4067568 \\
\hline $\log _{-} y_{j}$ & 1.052944 & 0.2971905 & 4.61 & 0.000 & 0.4185684 & 1.6673160 \\
\hline $\log _{-} y_{i}$ & 2.841473 & 0.6084920 & 4.49 & 0.000 & 1.453078 & 4.0098660 \\
\hline year & -0.1338227 & 0.0207131 & -6.46 & 0.000 & -0.1773392 & -0.0903062 \\
\hline cons & 245.6988 & 38.456800 & 6.39 & 0.000 & 164.90410 & 326.49350 \\
\hline
\end{tabular}

Source: Author Computed by STATA

\subsection{Conclusion and Policy Recommendations \\ 5.1 Conclusion}

The study attempted to analyze the impact of a Framework for EPA on EAC trade with the EU. A set of two equations were estimated for each EAC country: export and import gravity models. Ordinary Least Squares (OLS) was used in the estimation. The data series were tested for unit roots against the null hypothesis that the series contained unit roots using Levin-Lin-Chu unit root test. The series were found to be stationary in their log form with autoregressive of order one. The analysis indicates that the interim EPA had positive impact on Kenya and Tanzania exports to EU while Burundi, Rwanda and Uganda were negatively impacted although the coefficients were statistically not significant. EAC imports from EU into all EAC countries were positively impacted by EPA except for Burundi implying that EAC regional bloc is destined to become a net importer and frustrate its industrialization agenda. Moreover, real GDP of both EU and EAC countries as well as real GDP growth of the individual EAC countries had positive impact on increase in imports from EU and were mixed on the part of exports. Tanzania's exports to EU were found to be negatively impacted by her real GDP growth, indicating possibility of diversified export products and markets. Trade diversion effect was evident as all the exports and imports among EAC and EU decreased with time which implies that EAC countries were trading less during interim EPA compared with the trade prior to FEPA. This finding thus defeats the objective of EPA of increasing trade among the two partner blocs and becomes a disincentive for signing a full EPA as it suggests EAC have other more friendly markets than EU market. 


\subsection{Policy Recommendations}

The study was carried out to help build strong negotiation positions for EAC countries that reflect ability of their economies and win-win outcome. The analyses show that EAC countries would record low economic benefits and trade diversion effect by signing a full EPA. EAC were found to trade more with non-EU countries even with the implementation of the interim EPA since 2007 which suggests existence of non-tariff and non-quantitative restrictions such as high sanitary and phyto-sanitary standards instituted by the EU, supply constraint and low productivity in EAC, low production capacities in the EAC, logistical challenges in connecting the two markets, existence of EPAs with other competing blocs, low investments in EAC and lack of trade facilitation measures. This defeats the whole purpose of an FTA unless some other complimentary policies are adopted by EU to correct the misalignment. Therefore, the EAC economies should put more emphasis on the need to intensify their stance in the negotiations on "economic and development cooperation chapter" and outstanding issues in agriculture, rules of origin, export taxes, trade related investment measures, trade facilitation, most favoured nations (nondiscrimination) clause and the non-execution (human rights) clause as well as improve on Aid-for-trade, among others.

It is important for EAC countries to take precautionary measures in engaging the EU for negotiations as the aboutto-be concluded and consequentially signed full economic partnership agreement may turn out to be a one-sided and win-lose arrangement in favour of the EU. With the advanced technology, industrialization, abundant skilled labour force, high productivity, production efficiency and high investments in the EU countries, the EAC economies may find themselves as net importers, attracting stiff competition of their locally produced goods, low government revenue and de-industrialize as their markets will be flooded with cheaper imports originating in EU. The consequent will be decreased investment inflows, high unemployment, budget starvation, low production in the agriculture sector and ultimately economic slowdown.

There is a need also for EAC countries to conduct adequate preparations including carrying out an in-depth analyses and simulations of any international or regional trade policy instruments prior to signing agreements.

\section{References}

- $\quad$ Abedini, J. and Peridy, N. (2008): The Greater Arab Free Trade Area (GAFTA): An

- Amoah, B., and Loloh, W. F., (2009) Trade Balance and Policy Efficiency: Evidence from Ghana" Monetary Policy Analysis and Financial Stability Department, Bank of Ghana, Working Paper Series: WP/BOG-2009/02.

- $\quad$ Baier, S. L., and Bergstrand, J. H. (2007). Do Free Trade Agreements Actually Increase Members' International Trade? Journal of International Economics, 71, 72-95.

- Bergstrand, J.H. (1990): The Hecksher-Ohlin-Samuelson Model, the Linder Hypothesis, and the Determinants of Bilateral Intra-industry Trade; Economics Journal; 100(4): 1216-29

- Gani, A. (2008). Factors Influencing Trade Between Fiji And Its Asian Partners. Pacific Economic Bulletin Volume 23 Number 2, The Australian National University

- Grant JS, Lambert DM. (2008): Do Regional Trade Agreements Increase Members' Agricultural trade? American Journal of Agricultural Economics; 90(3): 765-782.

- Kalirajan, K. (2007): Regional Cooperation and Bilateral Trade Flows: An Empirical Measurement of Resistance; International Trade Journal; 21(2): 85-107.

- Kwaku, D. (1995), 'The African Economic Community: Problems and Prospects' ,Africa Today, 42, 4, 1-35

- $\quad$ Lee, H. and Park, I. (2007): In Search of Optimized Regional Trade Agreements and Applications to East Asia; World Econ 2007; 30(5): 783-806.

- Peridy N. (2005): The Trade Effects of the Euro-Mediterranean Partnership: What are the Lessons for ASEAN countries? Journal of Asian Economics; 16(1): 125-39

- Pöyhonen P. (1963). A Tentative Model for the Volume of Trade between Countries. Weltwirtschaftliches Archiv, vol. 90, pp. 93-99.

- $\quad$ Rahman, M. M. (2009). Australia's Global Trade Potential: Evidence from the Gravity Model Analysis Oxford Business and Economics Conference. St. Hugh's College, Oxford University, Oxford, UK, ISBN: 978-0-9742114-1-9.

- Rispens, R. K. E. (2009). Modern Economic Growth Theories and the "Miracle" of the East Asian Tigers, Erasmus University Rotterdam, School of Economics 
- Roy, M., and Rayhan. (2011). Trade Flows of Bangladesh: A Gravity Model Approach. Economics Bulletin, Vol. 31 No. 1 , 950-959.

- Tang, D. (2005): Effects of the Regional Trading Arrangements on Trade: Evidence from the NAFTA, ANZCER and ASEAN Countries, 1989-2000; Journal of International Trade and Economic Development; 14(2): 241-65.

- $\quad$ Timbergen, J. (1962): Shaping the World Economy, New York, NY: Twentieth Century Fund.

- UNECA. (2012). Assessing Regional Integration in Africa (ARIA V): Towards an African Continental Free Trade Area. Addis Ababa, Ethiopia, United Nations Economic Commission for Africa, Documents Publishing Unit, Addis Ababa.

- Viner, J. (1950). The Customs Union Issue Carnegie Endowment for International Peace, New York

- Wade R., (2001) East Asia's Economic Success: Conflicting Perspectives, Partial Insights Shaky Evidence, JSTOR World Politics, Volume 44, Issue 2, 270-320.

- World Bank (WB), Global Development Finance (GDF) April 2005, ESDS International, (Mimas) University of Manchester 